УДК 27.222-36:929 Сава Свети https://doi.org/10.18485/godisnjak.2017.12.3

Драгиша П. Бојовић* Универзитет у Нишу Филозофски факултет
Оригинални научни рад Примљен: 6. 10. 2017.

Прихваћен: 23. 10. 2017.

\title{
ДОМЕНТИЈАНОВ ОПИС ПРЕНОСА МОШТИЈУ СВЕТОГА САВЕ У СВЕТЛУ ХРИСТОВИХ ПРАЗНИКА*
}

Доментијаново Житије Светога Саве и даље представља неисцрпан извор нових тумачења и осветљавања појединих епизода у контексту односа према књижевној традицији, нарочито према Светоме писму и византијској химнографији. Коришћењем позајмица и симбола из наведене традиције Доментијан ствара христолики портрет свог главног јунака. У овом раду се посебна пажња придаје поређењима Светога Саве са Христом кроз опис преноса његових моштију из Бугарске у Србију. Први пут у нашој науци указује се и на Доментијаново коришћење дословних позајмица из Канона Пасхе Светог Јована Дамаскина.

Кључне речи: Свети Сава, пренос моштију, Христови празници, Васкрс, химнографија, Јован Дамаскин.

Доментијаново Житије Светога Саве јединствено је у нашој средњовековној књижевности и по намери писца да првог српског архиепископа пореди са самим Христом. Код других писаца и у другим делима ове књижевности не постоји таква изразита тенденција. Од Растковог необичног рођења до епизоде о преносу Савиних моштију из Трнова у Милешеву ређају се примери различитих и понекад неочекиваних поређења, која писац реализује кроз различите равни: чињење чуда, мисија, устројење

*dragisa.bojovic@filfak.ni.ac.rs

** Рад је настао у оквиру пројекта Министарства просвете, науке и технолошког развоја Насеља и становништво српских земаља у позном средњем веку, бр. 177010. 
Цркве, поуке ученицима, уподобљавање Христу у врлинама и подвигу. Доментијаново житије је поновљено јеванђеље, а опис Савиног живота има свој узор у опису Христових дела. Већ је Светозар Радојчић, непревазиђен у разумевању српских средњовековних текстова, као и у скоро интуитивном осећању најважнијих естетичких кретања у црквеној књижевности, ${ }^{1}$ препознао ту основну тенденцију Доментијановог дела, сматрајући чак да писац „прелази све границе допустивих поређења”: „Млади Растко уподобио се Господу своме 'када су у гробу војници чували његово пречисто тело, и његовом невидљивом силом покривен изиђе другим ликом посред војника који су га чували'. Доментијанова licentia poetika заиста је претерана, он упоређује младог Растка са васкрслим Христом" (Радојчић 1979: 218). Догађај се односи на почетак Савиног монашког живота, када је Растко обукао монашку ризу у светогорском манастиру Светог Пантелејмона. Ако се има у виду да и поређења у завршном делу Житија представљају аналогију са васкрслим Христом, онда можемо рећи да је почетак Савиног монашког живота и крај његовог животописа у знаку тих поређења.

Кулминација поређења са Христом остварена је, дакле, у завршници дела преко описа преноса моштију Светога Саве из Трнова у Милешеву. ${ }^{2}$ Кроз симболику Христових празника (Божић, Цвети и Васкрс), Доментијан користи прилику да свог учитеља пореди са самим Христом. ${ }^{3}$ У опису посебно доминира симболика Васкрса, јер подизање Савиног нетрулежног тела из гроба пружа прилику за подсећање на догађај Христовог Васкрсења. Сам пренос моштију обављен је највероватније после

\footnotetext{
${ }^{1}$ Нема сумње да је, поред велике ерудиције, оваквом Радојчићевом разумевању средњовековне књижевности допринео и његов однос према Богу, свакако лични, али и дубоко разумевање да је управо Бог централна личност преко које се остварују сви други егзистенцијални и естетички односи у средњовековном свету. О том личном односу видети, између осталог, и поглавље Радојчић и Бог у књизи Андреја Вујновића, Светозар Радојчић, живот и дело (Вујновић 2015: 20-30). Видети и Радојчићеву преписку са Александром Дероком: Споменица Светозара Радојчића 2009: 92. О својеврсном, посебном, односу ствараоца и тумача уметничког дела према Богу и божанској лепоти (метафорички руска душа) Радојчић надахнуто пише у раду Белешка уз један иитат из Сопоћана (Радојчић 1982: 195-198). У овом раду више је речено о суштини наше средњовековне уметности и књижевности него у многим другим, врло често заморним, студијама.

${ }^{2} \mathrm{O}$ овој теми, из других позиција у односу на овај рад, писале су Радмила Маринковић (1987) и Смиља Марјановић Душанић (2009).

${ }^{3}$ Томе доприносе и чести цитати и јеванђеља, алузије на новозаветне догађаје, као и честе паралеле које Светога Саву контекстуализују у јеванђељски оквир. Јеванђељске цитате из Доментијановог Житија идентификовали су С. Станојевић и Д. Глумац (Станојевић, Глумац, 136-213). О функцији јеванђеља у делу овог писца пише Снежана Милојевић (Милојевић 2015). Види и рад Љиљане Јухас Георгиевски: Библијске паралеле у функиији грађења јунака у Доментијановом Животу Светога Саве (1997).
} 
Васкрса 1237. године, што и самог писца и друге актере догађаја држи у празничном расположењу. ${ }^{4}$

На самом почетку описа Доментијан саопштава кога је све краљ Владислав окупио и повео на пут у Трново, где су већ почивале Савине мошти: „Сабра велики клир свога светога отачаства, богогласне светитеље, часне игумане и богоносне изабране чрнце, и попове и ђаконе, и сав чин црквени" (Доментијан 1988: 224). Одмах након тога писац наглашава да је краљ повео „изабране слуге свога великога краљевства”, али и „децу Преосвећенога”, што значи да је сабран и државни врх, али и представници Цркве, међу којима су важно место имали Савини ученици.

Већ сам опис поласка из Србије у Бугарску обилује снажним сликама и симболима: „И умне његове овце, Богом вођене, саме пођоше тражећи свога пастира, пресветлу Даницу, која је на истоку зашла под Земљу, а која им је пре показала истинити живот, и који их је учинио причасницима незалазног дана. И пођоше са радошћу веселим ногама, хотећи открити пресветло светило на истоку, богоразумну зраку која сија у срцу земље, сакривену свету ризницу многоценог бисера и од самог Господа уштеђену богољубној деци светога отачаства, од младости засађенога у дому Господњем, и који је, по речи пророчкој, као финик процветао по лицу целе васељене, и као кедар у Ливану умножио чеда своја, који и под земљом опет неувело цвета" (Доментијан 1988: 225). Овај је опис у знаку три симбола - позајмица из богослужбене поезије, нарочито из Канона Пасхе, чији је аутор Свети Јован Дамаскин. ${ }^{5}$ Први симбол је симбол светлости и везан је за догађај када су жене мироносице кренуле ка Христовом гробу уочи његовог васкрсења, „тражећи пре сунца Сунце које зађе негда у гроб", како се кажу шестој песми Канона Пасхе. ${ }^{6}$ Као што је из Светог

${ }^{4}$ У црквеном календару пренос моштију се празнује 19. маја.

${ }_{5}^{5}$ Цитати из Дамаскиновог Канона Пасхе преузети су из следећег превода: http://www. novisrbljak.narod.ru/PDF_files/Mojirad/pasha.pdf Види и: http://www.spc.rs/sr/vaskrsnji_kanon

${ }^{6}$ Аутор Канона Пасхе је Свети Јован Дамаскин, песник VIII века. Написао је још и ове каноне: на Божић, Богојављење, Педесетницу, Вазнесење, Преображење, Благовести, Успење, на спомене светих Апостола и светитеља: Василија Великог, Григорија Ниског, Иполита, Епифанија, Златоуста и многих преподобних и мученика, као и канон у част преподобног Романа Слаткопојца (Керн 2003: 57). Владика Атанасије Јевтић сматра да је Дамаскин написао око 90 канона. Овај аутор пише опширно о животу делу Светог Јована (Епископ Атанасије 2002: VII-LXXX). У овом тексту доноси и занимљиву историју настанка Канона Пасхе: „Светосаваитско предање каже да је игуман тога манастира благословио монасима Јовану и Козми, који су већ увелико постали познати по своме црквеном, богослужбеном песништву, да сваки од њих понаособ састави Пасхални канон (ниску од девет песама са тропарима). И они су то послушно учинили. Када су дошли пред игумана, сваки са својим Ускршњим каноном, Козма је уступио предност брату Јовану. Када је Јован отпевао Ирмос прве песме, са још две строфе, и почео трећу песму, коју смо малочас навели, Свети Козма је одједном поцепао свој папир, 
јеванђеља познато жене мироносице су пре изласка сунца кренуле на гроб Христов: „И врло рано у први дан недјеље дођоше на гроб око изласка сунца" (Мк 16,2). И Савини ученици полазе да нађу светлост. ${ }^{7}$ У Канону Христос се назива Сунцем, а у Доментијановом опису Сава је пресветла Даница, пресветло светило и богоразумна зрака, која је „на истоку зашла под земљу” као што, у Канону, Христос „негда зађе у гроб”. Очигледно да ову слику Доментијан позајмљује из наведеног канона и тиме пореди Саву са Христом. ${ }^{8}$ Следећи је симбол незалазног дана, који симболише вечну светлост и Царство небеско, у коме нема таме. У деветој песми Канона Пасхе пева се: „Подај нам да се потпуно сјединимо с Тобом, у незалазни дан Царства твога.” У поменутом Доментијановом опису говори се да је Сава своје ученике и стадо коме је био пастир „учинио причасницима незалазног дана", па се и овде може говорити о утицају Васкршњег канона на Доментијанову симболику. Последњи симбол је везан за псаламску симболику $($ П. 91,13$)$ и односи се на живот праведника и моћ умножавања, што симболишу финик и кедар (Атанасије Велики 2003: 238). У претходном Доментијановом тексту говори се о благодатном умножавању Савиних ученика, што писац, по нашем мишљењу, преузима из већ написане Службе преноса моштију Светога оча нашега Саве (на стиховње стихире, глас 2, подобан), коју је највероватније написао Савин ученик Атанасије: „У дому Божјем процветао си као финикс и као кедар умножио јеси чеда своја, стога ти свети пренос славимо" (Трифуновић 1970: 39$).{ }^{9}$ Ова служба спада у најстарије текстове о Светоме Сави и могла је извршити утицај на Доментијаново житије, као и неки други ранији текстови. ${ }^{10}$

рекавши: 'После овога, нема шта више да се каже!' (...) Не знамо какав је био Ускршњи канон Светога Козме, али држимо да је Дамаскинов Пасхални канон заиста ненадмашан, како по дубини садржаја, тако и по песничким узлетима, надахнутим усхићењима, светлорадосним доживљајима Христовог и нашег Васкрсења" (Епископ Атанасије 2002: LXXII).

${ }^{7}$ О богатој симболици светлости у Доментијановом житију већ је доста писано. Упућујемо на радове Ђорђа Трифуновића (1972), Станислава Хафнера (1984), Милорада Лазића (1997) и Данијела Дојчиновића (2013).

${ }^{8}$ Када је реч о богослужбеним позајмицама у Доментијановом делу, до сада је указано само на неколико примера: Станоје Станојевић и Душан Глумац у Житију Светога Саве идентификују Стихиру-антифон на Вели четвртак на бденију (Станојевић, Глумац, 196). Влаховић у раду Литургички материјал у старим српским биографијама ХІІІ века наводи стихире - позајмице из На Господи возвах, На воздвижење часног крста, дужу позајмицу из песме Васкрсни седален, као и стихове из Акатиста Пресветој Богородиции (Влаховић, 350). О овом питању видети и: Александра Костић Тмушић. Богослужбене песме ужитијном опусу јеромонаха Доментијана и Теодосија Хиландарйа (Ниш 2014).

${ }^{9}$ У Житију се за Саву каже „да је као финик процветао по лицу целе васељене, и као кедар у Ливану умножио чеда своја" (Доментијан 1988, 225).

${ }^{10}$ О овом питању видети: Богдановић 1980 . Склони смо мишљењу да је међу Савиним ученицима извршена подела у писању култних списа о учитељу. Тако је Доментијан написао 
У даљем опису, пре него се врати васкршњој симболици, Доментијан бележи неколико важнијих догађаја: долазак Краља и пратње у Трново, сусрет и невоље са бугарским царем, страшно виђење бугарског цара након чега одлучује да дозволи пренос моштију, света литургија и надгробна пјенија за покој Преосвећенога. Мошти из гроба подиже отац Атанасије, кога Доментијан назива богоносним и свељубазним (Савиним) сином. ${ }^{11}$ То је прилика да се писац врати симболици Васкрса и мотиву подизања тела из гроба односно васкрсењу из гроба. Над гробом у Трнову Атанасије изговара плач, чији први део је дословно преузет из девете песме Канона Пасхе. Само је Христово име замењено Савиним односно синтагмама „богогласни Сава” и „боголепни Сава”, а слатком гласу додат је израз преосвећени: "О Божија, о љубазна, о слаткога и преосвећенога гласа, богогласни Саво; истинито се обећа да ћеш са нама бивати до скончања века, боголепни Саво; а ми љубима чеда твоја, имајући те као државу и богомисаону наду, сада се радујемо" (Доментијан 1988: 227). У Канону стихови гласе овако: „О, божанског, о, љубљеног, о, најслађег твога гласа, јер си нелажно обећао да ћеш бити са нама до свршетка века, Христе. Њега верни (за) утврђење наде имајући, радујемо се.” Атмосфера Светле седмице и празника Христовог Васкрсења преноси се, доласком Савиних ученика, из једног простора у други, из Србије у Бугарску, а химнографске позајмице у Доментијановом опису стварају амбијент Васкршњег празника, чиме се и на непосредан начин пореди новозаветни догађај Христовог васкрсења са вађењем из гроба моштију Светога Саве. Тиме је онај, који је могао, како сведочи Доментијан, и мртве васкрсавати, али се због смерности клонио тога, и у овоме постао подобан Господу Исусу Христу. На догађај Христовог Васкрсења подсећа и облачење Светога Саве: „А богосветла чеда његова, ваистину нашавши велику ризницу, тога самога Преосвећенога, обукавши га у пресветле ризе, и обвивши часним поњавама, управише га на пут ка његову отачаству" (Доментијан 1988: 227). У јеванђељима се описује догађај када ученици, након распећа,

житије, док су Атанасије, а вероватно и други ученици, писали химнографске текстове. Поред Доментијановог житија постојали су и други житијни извори, о чему је, пишући и сам Савино житије, белешку оставио потоњи хагиограф Теодосије Хиландарац: „А ово нисам примио само слушањем, него од његових часних ученика, његових сапосника и у туђиновању сапутника и на путовању сатрудника што као пребогату ризницу или наследство отачаско стаду његову за собом писмено оставише" (Теодосије 1988: 102).

${ }^{11}$ Богоносним Доментијан у овом житију назива само Светог Саву, његовог ученика и наследника на архиепископском престолу Арсенија и ученика Савиног Атанасија. Симболика богоносца везана је за име Светог Игњатија Богоносца са којим Доментијан експлицитно пореди Саву (Доментијан 1988: 101, 216). 
облаче тело Христово: „Тада узеше тијело Исусово, и обавише га платном с мирисима, као што је обичај у Јудејаца да сахрањују" (Јн 19, 40).

Након тога следи Доментијаново подсећање на догађај кад су слуге персијског цара Авгара, „пуни великог страха”, у Витлејему насликали и пренели у своју земљу икону Христову и његове мајке: „И као што они персијски волсви од Витлејема града пречисти образ Господњи насликан и његове пречисте Матере, пуни великога страха однеше тајно у своју земљу, истим начином и чеда овога Преосвећенога, обузети великим страхом и са великом журбом утекоше тајно од града Трнова, не мислећи да ће однети толики дар од тога богољубивог цара."12 Писац, по страху који су мудраци имали, то пореди са преносом моштију Светога Саве, али и подсећа да је то истовремено велики дар који носе од богољубивог цара. Овде се експлицитно асоцира да се Сава уподобио самоме Христу и да је његов лик уподобљен лику самога Христа. За причу о преносу Савиних моштију Доментијан није могао наћи другу паралелу везану за Господа Исуса Христа, већ само ову о преносу његове иконе.

Доментијан даље говори о чудима Светога Саве, која су се догађала у Трнову. Међу њима је и чудо са монахом Неофитом, којем се посвећује посебна пажња. Овом приликом скрећемо пажњу на само један детаљ, који се, такође, може довести у вези са симболиком Васкршњег празника. Монах Неофит, који је од пијанства заспао у цркви, на Савином гробу, пробудиће се здравим и проходаће, без коришћења штака, „у појање петлова". Доментијан сигурно зна да је у древној цркви било предвиђено да Васкршње бденије траје „док не запоје први петао” (Мирковић 1961: 176), те да појање петлова има снажну богослужбену симболику везану за Васкршње празновање. Тренутак појања петлова одваја пост од причешћа,

${ }^{12}$ Ова прича није сачувана у библијском већ у апокрифном тексту, а прича из апокрифног текста ушла је у чувену Божићну беседу Светог Јована Дамаскина. Бојан Миљковић сматра да је то место Доментијан највероватније преузео из Дамаскинове Божићне беседе (Миљковић 2008: 190): „А Дете сеђаше на земљи, започевши /замало, како је Она говорила,/ другу годину, имајући делимично лик Родитељке. Она пак беше висином малога раста, а телом младолика, боје као зрелога жита, и прелепе косе, сплетене око главе. А они, имајући са собом (способног) слугу живописца (који их наслика), понеше слику Њих обоје у (своју) земљу; и поставише (jе) у свој храм да јој се клањају сви...” (Јован Дамаскин 2002: 22). У широј верзији апокрифа о овом догађају се говори на следећи начин: „Дете сеђаше на земљи, као да две године има. Личише на мајку. Породиља беше висока телом, тамни изглед имаше, округлог лица и уплетене косе. Њихове слике у своју земљу понесмо. И полажисмо их својим рукама у Диоптово светилиште...” (Јовановић 2005: 39). У краћој верзији апокрифа стоји: „Ова три звездочатца говораху халдејским језиком. И чувши ту зограф од њих шта говоре, одмах наслика свету деву Марију и она три лица која видеше. И рекоше између себе: Ово је Бог велики над свим боговима које видесмо данас!” (Јовановић 2005: 50). О литератури која се односи на апокриф и о одјеку ове приче у сликарству видети: Миљковић 2008: 190-191. 
бдење од евхаристије, један циклус богослужбених песама од других. Чудо са Неофитом је једно од многих који чини Свети Сава, а које је у ствари поновљање Христових чуда. Неофитово подизање са Савиног гроба је слика тријумфа живота из гроба, коју симболише васкрсли Христос.

У даљем опису преноса моштију евоцирају се они догађаји из Новог завета који служе као погодне паралеле за илустровање кретања поворке и дочека моштију. Прво се истиче паралела са звездом и мудрацима са истока, чиме се у јеванђељима наговештава рођење Господа Исуса Христа. Сава се пореди са звездом, а његова духовна чеда су мудраци, који иду самоме Христу, „друга богозарна источна звезда са великом радошћу води друге волхве, богољубну децу своју” (Доментијан 1988: 231). Реч је о догађају који претходи Христовом рођењу и који је описан у Јеванђељу по Матеју (2, 1-12), а чита се на литургији на Дан Рождества Христовог: „А кад се Исус роди у Витлејему јудејскоме у дане Ирода цара, гле, дођоше мудраци од Истока у Јерусалим и рекоше: Гдје је цар јудејски који се роди? Јер видјесмо његову звијезду на Истоку и дођосмо да му се поклонимо. Кад то чу цар Ирод, уплаши се, и сав Јерусалим са њим. И сабравши све првосвештенике и књижевнике народне, питаше их гдје ће се Христос родити. А они рекоше: У Витлејему јудејскоме; јер је тако пророк написао: и ти Витлејеме, земљо Јудина, ни по чем ниси најмањи међу кнежевима Јудиним; јер ће из тебе изићи Вођа који ће напасати народ мој Израиља. Онда Ирод, тајно дозвавши мудраце, сазнаде од њих када се појавила звијезда. И пославши их у Витлејем, рече: Идите и распитајте се добро за дијете, па када га нађете, јавите ми, да и ја дођем да му се поклоним. А они, саслушавши цара, пођоше, и гле, звијезда, коју су видјели на Истоку, иђаше пред њима док не дође и стаде одозго гдје бјеше дијете. А кад видјеше звијезду, обрадоваше се веома великом радости. И ушавши у кућу, видјеше дијете са Маријом матером његовом, и падоше и поклонише му се, па отворивши ризнице своје принесоше му даре: злато, тамјан и смирну. И примивши у сну заповјест да се не враћају Ироду, другим путем отидоше у земљу своју."

Као што се може видети, путовање Савиних ученика ка Савином отачаству, практично ка месту где је рођен њихов учитељ, има паралелу у путовању мудраца, које звезда води ка месту Христовог рођења. То је она иста светлост, која је дошла са неба и она светлост, која је устала из гроба.

Сам дочек моштију, када се поворка приближила отачаству, пореди се са Христовим дочеком у Јерусалиму односно са празником Цвети: „И када се приближио земљи свога отачаства, а преосвећени отац наш богоносни велики сапрестолник тога Преосвећенога, богогласни архиепископ 
Арсеније са свеосвећеним епископима и са часним игуманима, и са свом децом црквеном, и као што јерусалимска чеда изиђоше у сусрет Христу са гранчицама и гранама, вапијући и говорећи: 'Благословен који греде у име Господње, цар Израиљев', и чеда овога Преосвећенога сретоше га са богохвалним песмама место масличних грана, узашиљући различне гласове ка вишњему за покој Преосвећенога, и раширивши љубавна срца раније запојена боголепним његовим учењем и услађена богоговорним језиком његовим, течаху на сусрет издавна жељеноме, богосветлој зраци која иде од истинитог сунца, и славују богогласног јеванђелског учења, који им је бодрим умом и неуснулим очима испрва објавио божаствену радост неизречиве благодати" (Доментијан 1988: 231). Као што је познато, саме Цвети претходе празнику Христовог Васкрсења, а радост која испуњава дочек Христа у Јерусалиму наговештава радост Христовог Васкрсења. Доментијановом опису преноса моштију у Србију ова асоцијација даје ту емотивну димензију. Веома је експлицитна и паралела између израиљског и српског рода односно између „јерусалимских чеда” и деце Савиног отачаства.

У епилогу описа потенцира се сусрет са „богосветлом зраком” која долази од „истинитог сунца”, а то је оно Сунце из Канона Пасхе, које „негда зађе у гроб". ${ }^{13}$ Савин долазак се посматра у контексту његовог повратка из Свете Земље и тај долазак име две деоница, једна од Јерусалима до Трнова, а друга од Трнова до Милешеве. То је пут једне светлости, која ће у Милешеви као „сунце да сија”, чиме слика Савиног уподобљавања Христу добија завршни облик. ${ }^{14}$ Транслацију моштију прати пут незалазне

${ }^{13}$ Симболици светлости, која заузима важно место у целом опису преноса моштију, доприноси и Доментијаново подсећање на пророчке речи Светог Симеона о Светоме Сави: „Оптећићеш истоке и западе, као и сунце, осијавши долине и брда, и испитавши све неиспитане путеве Владике свога, и од истока доћи ћеш к мени, носећи превелико извешће деци свога отачаства, и заједно ћемо се насладити општега блаженства од љубитеља нашега Христа" (Доментијан 1988: 226).

${ }^{14}$ Доментијан на другом месту сведочанство светих отаца Свете Земље и Свете Горе да је цео Савин живот био на небесима односно уподобљен небеском цару: „Овога светога ми не упоређујемо ни ка земаљским људима ни ка небесним звездама, ни ка месецу који просвећује ноћ, ни ка самом истинитом сунцу небесном, које је сваком топлотом огрејало све, и сваким духовним и телесним требовањем. Јер овај свети - рекоше - не поживе себи на земљи ни овај један дан, но цео живот свој овога света посла ка небесима, који и нађе ходећи још жив у телу, а уз то се још из матерње утробе јави обливен благодаћу Божјом, и јави се љубазан небесном цару и силама небесним; и постаде достојан саврсник апостолима и мученицима, носећи на себи зраку ових небесних, и служећи Господу дан и ноћ, не извијањем речи, но у простоти срца; коме се, рекоше, удивише анђели,и преудивише људи, и заволеше га и земаљски цареви и сувише, и одликоваше га великим частима као једнога од небесних, и сви који живе на земљи, правоверни мали и велики, његовим весељем бише обвесељени и његовим богатством бише обогаћени" (Доментијан 1988: 203-204). 
светлости ка незалазном дану Царства Христовог. Љубљени Савин ученик, Доментијан у мајсторском стваралачком маниру, завршава Савино житије стварајући још једну особену паралелу између свог духовног учитеља и књижевног јунака, са једне стране, и „љубитеља Христа”, са друге стране. Христови празници (Васкрс, Божић и Цвети) и њихова симболика контекстуализовани су кроз причу о преносу моштију, при чему је предност дата обрнутој хронологији - прво се прави паралела са Васкрсом, па тек онда, у опису кретања ка Србији, асоцира се на Божић и Цвети, као и на догађај о преносу иконе Христове из Витлејема у Персију. И сама Васкршња служба, на чији смисао се угледа Доментијан у опису преноса моштију, представља учвршћену „везу главних догађаја из црквене године”, чиме та служба „постаје јединствена грађевина чији је врх у Ускрсу” (Мирковић 1961: 199). Како у служби, тако и опису преноса моштију, асоцира се на најважније Христове празнике. Може се закључити да Доментијанов прозни текст прати основне идеје васкршње химнографије.

Треба рећи да су и други делови овог описа у функцији поређења Саве са Христом. Својеврсна химна коју узноси бугарски цар у част Светога Саве састављена је из библијских цитата, којима се доводе у везу Сава и Христос. Након тога се истиче мноштво чуда које је учинио Христос, што служи као увод у опис чуда Светога Саве у Трнову. ${ }^{15}$ Поред чуда са Неофитом, које смо поменули, писац наводи да се „дотицајем Преосвећенога тела његова неизмерном силом и безбројном својом милошћу дарова слепима прогледање и хромима ход и глухима слух и болнима исцељење" (Доментијан 1988: 228). Потенцирају се и речи бугарског Патријарха Јоакима о потреби описивања тих чуда, а Доментијан експлицитно тврди да су чуда и описана. У том случају, реч је о једном од најстаријих култних списа о Светоме Сави, који је настао у Бугарској, а који, на жалост, није сачуван.

Пошто опис преноса моштију представља финале житија, Доментијан користи прилику да ефектним аналогијама још једном потврди непрестану стваралачку тенденцију поистовећивања Светог Саве са самим Христом. Утврдили смо да, поред библијских места, значајно се користи позајмицама из богослужбене поезије (Канон Пасхе Светог Јована Дамаскина), а раније је већ показано (Миљковић 2008) да је писац користио и Дамаскинову Беседу на Свето Христово рођење. Нарочито је важно истаћи да Доментијан, као и древни химнопојац, кроз васкршњу тематику сабира важне догађаје из Христовог живота користећи их као паралеле или аналогије у илустровању светости Архиепископа Саве.

\footnotetext{
${ }^{15}$ О поетици чуда види: Бојовић 2014.
} 


\section{ИЗВОРИ}

Доментијан 1988: Живот Светог Саве и Живот Светог Симеона, (пр.) Р. Маринковић, Београд: Просвета, Српска књижевна задруга. Јован Дамаскин 2017: Канон Пасхе: http://www.novisrbljak.narod.ru/PDF_files/Mojirad/pasha.pdf; http://www.spc.rs/sr/vaskrsnji_kanon.

Јован Дамаскин 2002: Празничне беседе. Превод са грчког и увод Епископ Атанасије (Јевтић). Београд: Српска књижевна задруга.

Јовановић 2005: (пр.) Т. Јовановић, Апокрифи новозаветни, Београд: Просвета, Српска књижевна задруга.

Теодосије 1988: Житија,(пр.) Д. Богдановић, Београд: Просвета, Српска књижевна задруга.

Нови Завјет, 2012: превод Комисије Светог архијерејског синода СПЦ, Београд: Библијско друштво.

Трифуновић 1970: (пр.) Ђ. Трифуновић, Србљак. Службе, канони, акатисти, књига прва, Београд: Српска књижевна задруга.

\section{ЛИТЕРАТУРА}

Атанасије Велики Свети, Василије Велики Свети 2003: Благослови, душо моја, Господа. Свети оци тумаче Псалтир, превод са старогрчког Антонина Пантелић, Београд: Православна мисионарска школа при храму Светог Александра Невског.

Богдановић1980: Д. Богдановић, Најстарија служба Светом Сави, Београд: Српска академија наука и уметности.

Бојовић 2014: Д. Бојовић, Поетика чуда. Зборник Матице српске за книжевност и језик, књ. 62, св. 3, Нови Сад, 639-648.

Влаховић 1932: В. Влаховић, Литургички материјал у старим српским биографијама XIII века, Богословље, год. VII, св. 4, Београд, 335-351.

Вујновић 2015: А. Вујновић, Светозар Радојчић: живот и дело, Београд: Завод за уџбенике.

Дојчиновић 2013: Д. Дојчиновић, Мисао о свјетлости од Светог писма до Доментијана, Наука и традиција (филолошке науке), Посебна издања - научни скупови, књ. 7, т. 1, Пале: Универзитет у Источном Сарајеву, Филозофски факултет, 591-600.

Јевтић 2002: Атанасије Епископ Јевтић, Епоха, живот, дела, беседе Светог Јована Дамаскина, у: Свети Јован Дамаскин, Празничне беседе, Београд: Српска књижевна задруга. 
Јухас-Георгиевска 1997: Љ. Јухас-Георгиевска, Библијске паралеле у функцији грађења јунака у Доментијановом Животу Светога Саве, $C p$ пска књижевност и Свето писмо, Београд: Научни састанак слависта у Вукове дане, 26/1, 51-60.

Керн 20003: Кипријан архимандрит, Литургика са химнографијом и хеортологијом, Шибеник: Истина.

Костић Тмушић 2014: А. Костић Тмушић, Богослужбене песме у житијном опусу јеромонаха Доментијана и Теодосија Хиландарца, Црквене cmудије, 11, Ниш: Центар за црквене студије, 513-526.

Лазић 1997: М. Лазић, Естетика Доментијанових житија, Подгорица: Октоих.

Маринковић 1987: Р. Маринковић, Доментијанов опис преноса моштију Светога Саве из Трнова у Милешеву, Милешева у историји српског народа, Београд: САНУ, 121-135.

Марјановић Душанић 2009: С. Марјановић Душанић, Реликвије, чудотворења и furta sacra. Прилог истраживању српско-бугарских односа током четврте деценије XIII века, Зборник радова Византолошког инстиmута, XLVI, Београд, 281-298.

Милојевић 2015: С. Милојевић, Јеванђеље у Доментијановом Животу Светога Саве, Зборник радова Филозофског факултета, 2, Косовска Митровица, 63-90.

Миљковић 2008: Б. Миљковић, Житија Светога Саве као извори за историју средњовековне уметности, Београд: Византолошки институт САНУ.

Мирковић 1961: Л. Мирковић, Хеортологија или историјски развитак и богослужење Православне источне иркве, Београд: Свети архијерејски синод СПЦ.

Радојчић 1979: С. Радојчић, Лик Светога Саве у Доментијановом Животу и подвизима архиепископа све српске и поморске земље преподобног оца и богоносног наставника Саве, Сава Немањић - Свети Сава. Историја и предање. Београд: САНУ, 215-221.

Радојчић 1982: С. Радојчић, Одабрани чланци и студије 1933-1978. Београд: Издавачки завод Југославија, Нови Сад: Матица српска.

Споменица Светозара Радојчића. Поводом стогодишњице рођења. Београд: Филозофски факултет, 2009.

Станојевић, Глумац 1932: С. Станојевић, Д. Глумац, Св. Писмо у нашим старим споменииима, Београд: Српска краљевска академија.

Трифуновић 1972: (пр.) Ђ. Трифуновић, Доментијан песник светлости. Стара книжевност, Београд: Нолит. 
Хафнер 1984: С. Хафнер, Доментијан и Слово о закону и благодети Митрополита кијевског Илариона, Глас CCCXL Cрпске академије наука и уметности, Одељење језика и књижевности, књ. 12, Београд, 61-76.

Dragiša P. Bojović

\section{DOMENTIJAN'S DESCRIPTION OF THE TRANSFER OF THE RELICS OF ST. SAVA IN THE LIGHT OF FEASTS OF CHRIST}

\section{Summary}

Domentijan's Life of St. Sava still represents an inexhaustible source of new interpretations and clarifications of particular episodes in the context of connections to the literary tradition, in particular to the Holy Scriptures and Byzantine hymnography. Although our discipline has long pointed to the tendency of this author to compare his hero, St. Sava, with Christ himself, interpretations of various such analogies are still not exhausted. Taking advantage of loans and symbols from the mentioned tradition, Domentijan uses the description of the transfer of the relics to compile the final image of St. Sava as Christ. Thereby, the writer uses word-for-word loans from The Paschal Canon by St. John Damascene. This fact is stressed here for the first time in our discipline. Having in mind the themes and symbolism of Easter poetry, Domentijan also incorporates motives from other feasts of Christ into his Easter symbolism - such as that of Christmas and Palm Sunday. 